\title{
Stable Emulsion Regions of Surfactant-Oil-Water and Surfactant-Oil-Water-Long Chain Alcohol Systems
}

\author{
Akira Tsugita, Yasushi Nishijima, and Tsunetaka Sasaki* \\ Cosmetics Laboratory, Kanebo, Ltd. (5-3-28, Kotobuki-cho, Odawara, Kanagawa) \\ * Department of Chemistry, Faculty of Science, Tokai University (1117, Kitakaname, \\ Hiratsuka, Kanagawa)
}

\begin{abstract}
A ternary diagram for nonionic surfactant-oil-water system was studied and the region of stable and strongly opaque emulsion (the region $\mathrm{E}_{1}$ ) was determined on the diagram. It was found that the $\mathrm{E}_{1}$ region existed only within the two-phase region consisting of a viscous isotropic phase and an oil phase, and that at least 10\% surfactant was necessary to obtain this region.

The quarternary system containing cetostearyl alcohol in addition to the ternary system was also examined. Addition of the alcohol produced a new stable region of strongly opaque emulsion (the region $\mathrm{E}_{2}$ ) besides $\mathrm{E}_{1}$. The appearance of the region $\mathrm{E}_{2}$ reduced the minimum surfactant concentration to obtain the stable and strongly opaque emulsion to about $2 \%$. Similar effect was observed for behenyl alcohol of cosmetic grade, which is also a mixture of alcohols. However, pure alcohols of carbon numders from 12 to 16 lacked the ability to form the $\mathrm{E}_{2}$ region. Those of carbon numbers of 18 and 20 gave the $\mathrm{E}_{2}$ region but only above the surfactant concentration of $5 \%$.
\end{abstract}

\section{Introduction}

Emulsions, which are utilized in cosmetics and pharmaceuticals, are prepared by mixing oils and aqueous solutions usually in the presence of surfactants. Here, amphiphilic substances such as long chain alcohols, long chain acids, and monoacylglycerols are widely used to in = crease the stability of emulsions. Further, in order to obtain smooth and non-greasy emulsions for practical application, and to preserve them effectively from decay, it is preferable to minimize the surfactant concentration.

Several studies ${ }^{13 \sim 7)}$ have already been reported concerning the formation of emulsion regions in some ternary or quarternary diagrams, and the authors also intended to examine the diagrams for a surfactant-oil-water system and surfactantoil-water-long chain alcohol systems to add informations from the practical as well as fun= damental points of view.

Lachampt et al. ${ }^{1}$ investigated the ternary diagrams for hydrophilic surfactant-oil-water systems and briefly referred to the formation of a stable emulsion region. They further studied in detail the diagrams for mixed emulsifier-oilwater systems with varying ratios of hydrophilic and lipophilic surfactants, and discussed the relation between the ratio and the minimum emulsifier concentration necessary to obtain fine emulsions $^{2)}$. However, they did not refer to further details of emulsion stability and the state of the fine emulsions.

The present study pays attention to the emul= sion stability and its opacity which are the important factors for the practical emulsion products. First, the authors used a surfactantoil-water ternary system similar to that used by Lachampt et al. ${ }^{1)}$, and determined the region of stable and strongly opaque emulsion on the diagrams. Then, some quarternary diagrams were examined by adding long chain alco= hols as the fourth component to the above three component systems.

By comparison of these ternary and quarter= nary diagrams, the effect of addition of long: 
chain alcohols on the formation of the region of stable and strongly opaque emulsions, was studied. From these results, the conditions for the formation of above mentioned regions with minimum surfactant concentrations were obtained.

\section{Experimental}

\subsection{Materials}

The surfactant used was oleyl poly (oxy= ethylene) (10) ether (Nikko Chemicals Co., Ltd.) which is simply called the surfactant hereafter. The cloud point of its $5 \%$ aqueous solution was $64^{\circ} \mathrm{C}$. Liquid paraffin of cosmetic grade (Carnation, the product of Witco $\mathrm{Chem}=$ ical Corp.) was used which is called the oil. Water used was deionized. The long chain alcohols used were cetostearyl alcohol, behenyl alcohol, both of cosmetic grade, and five pure alcohols, the carbon numbers of which are 12 , $14,16,18$, and 20. The compoitions or the purities determined by GLC and the melting points (mp) of these compounds are as follows.

Cetostearyl alcohol (Kokyu Alcohol Kogyo Co., Ltd.), $\mathrm{C}_{16} \mathrm{OH}: 57 \%, \mathrm{C}_{18} \mathrm{OH}: 35 \%, \mathrm{C}_{14} \mathrm{OH}$ : $6 \%$, others (3 peaks): $2 \%, \mathrm{mp}: 54^{\circ} \mathrm{C}$; behenyl alcohol (Nippon Oils \& Fats Co., Ltd.), $\mathrm{C}_{22}$ $\mathrm{OH}: 53 \%, \mathrm{C}_{20} \mathrm{OH}: 22 \%, \mathrm{C}_{18} \mathrm{OH}: 22 \%$, others (2 peaks): $3 \%, \mathrm{mp}: 69^{\circ} \mathrm{C}$; 1-dodecanol $\left(\mathrm{C}_{12}\right.$ $\mathrm{OH}$ : Wako Pure Chemical Industries, Ltd.), purity $98 \%, \mathrm{mp}: 24^{\circ} \mathrm{C}$; 1-tetradecanol $\left(\mathrm{C}_{14} \mathrm{OH}\right.$ : Wako Pure Chemical Industries, Ltd.), purity: 98\%, mp : $39^{\circ} \mathrm{C}$; 1 -hexadecanol $\left(\mathrm{C}_{16} \mathrm{OH}\right.$ : Tokyo Kasei Kogyo Co., Ltd.), purity : $99 \%$, mp : $50^{\circ} \mathrm{C}$; 1-octadecanol $\left(\mathrm{C}_{18} \mathrm{OH}\right.$ : Tokyo Kasei Kogyo Co., Ltd.), purity $98 \%, \mathrm{mp}: 60^{\circ} \mathrm{C}$; 1 -eicosanol $\left(\mathrm{C}_{20}\right.$ $\mathrm{OH}$ : Tokyo Kasei Kogyo Co., Ltd.), purity: 95\%, mp : $62^{\circ} \mathrm{C}$.

\subsection{Preparation of Samples}

A glass tube was sealed after given amounts of components were introduced, dipped in a boiling water bath for $10 \mathrm{~min}$, and shaken. Further, dipping in the bath for $5 \mathrm{~min}$ and shaking were repeated twice. It was then cooled slowly to room temperature while being turned gently, and stored in the bath of constant temperature at $20^{\circ} \mathrm{C}$.

\subsection{Measurements and Terms Used}

Opacity (whiteness) of samples was determined by measuring the transmittance at $550 \mathrm{~nm}$ using a cell of $0.15 \mathrm{~mm}$ thickness. Liquid paraffin was used as a reference substance. Transmit= tance, $T$, is expressed by

$$
T=I / I_{0},
$$

where $I_{0}$ and $I$ are the intensities of light transmitted through the reference substance and sample, respectively.

The sample of $T$ being less than 0.01 is defined as a strongly opaque emulsion (abbre $=$ viated as s.o.e.). The value of 0.01 was adopt $=$ ed referring to the opacity of most practical emulsions which show strong light scattering by dispersed droplets.

The stability of samples was determined a month after preparations. If no separation of oil or aqueous phase is observed within a month, the system is regarded as stable.

Ternary and quarternary diagrams were drawn with varying proportions of the components. The content of fourth component is indicated by its gram number per $100 \mathrm{~g}$ of the sum of the other three components. The identification of phases and the determination of their bound = aries were made on the basis of polarizing microscopic observations, visual observations on turbidity, and transmittance measurements.

\section{Results and Discussion}

\section{$3 \cdot 1$ Surfactant-Oil-Water Ternary System}

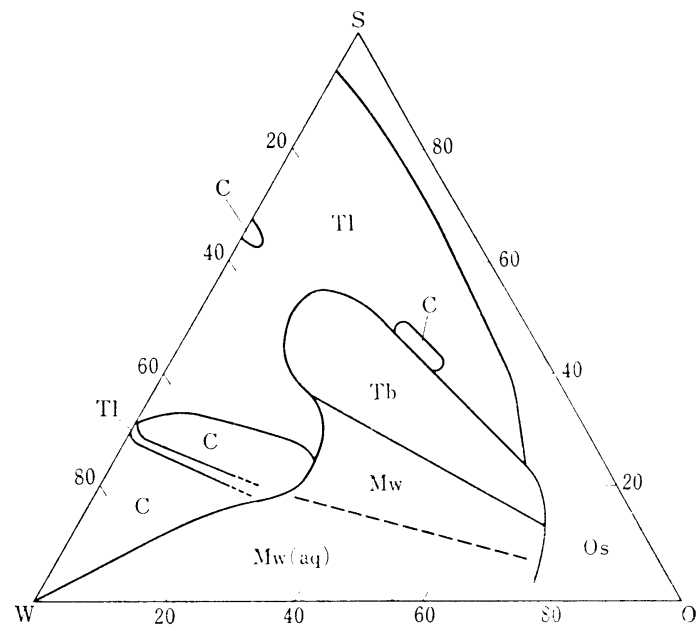

$\mathrm{C}:$ clear, $\mathrm{Tl}:$ translucent, $\mathrm{Tb}:$ turbid, Mw : milky white, Mw (aq): milky white (aqueous phase separated), Os : Oil separated.

Fig.-1 General appearances of surfactant-oilwater system. 
Fig. -1 shows the general appearances of the surfactant $(\mathrm{S})$-oil $(\mathrm{O})$-water $(\mathrm{W})$ ternary system. $\mathrm{C}, \mathrm{Tl}$, and $\mathrm{Tb}$ denote the regions of clear, translucent, and turbid systems, respectively. $\mathrm{Mw}$ is the region of a stable milky white system which includes a "stable s.o.e. region" as shown later. $\mathrm{Mw}(\mathrm{aq})$ is the region of an unstable milky white system, where the aqueous phases are easily separated. The system in a region Os readily separated an oil phase.

Fig.-2 shows the diagram of $T$ for the same ternary system. On either side of a relatively low water content or a relatively low oil content, $T$ was considerably high. The change in com $=$ position of the system from the middle part to the bottom of the diagram caused the decrease in $T$, and the increase in opacity. The s.o.e. region was devided into two parts; a stable $\left(E_{1}\right)$ and an unstable s.o.e. regions as shown in Fig.-2. Samples in $E_{1}$ were usually semi-solid state, whereas in the unstable s.o.e. region, samples were fluid and they readily separated aqueous phases.

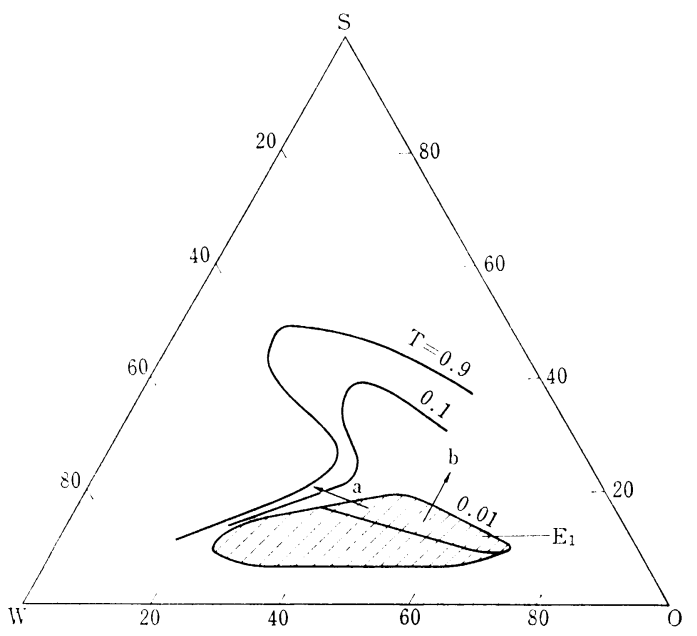

T:transmittance. $\square$ : stable s.o.e.region,

$\square$ : unstable s.o.e.region.

Fig.-2 Transmittance of surfactant-oil-water system.

The light scattering from the emulsion drops lets may be generally expected to be small and $T$ may be high, when the droplets are too fine or too coarse compared with the wave length of the visible light. Change of the composition along the direction "a" in Fig.-2 caused the decrease in the size and the number of oil droplets, resulting in the increase in $T$. The increase in $T$ with changing composition along the direction "b" in Fig. -2 may be explained by the increase in the size of oil droplets and probably by the decrease in the difference of refractive indices between a dis= persed phase (oil) and a continuous phase.

Fig. $-\mathbf{3}$ shows the ternary phase diagram for the same system surfactant-oil-water. $\mathrm{N}$ and $\mathrm{M}$ denote neat and middle phases. $I_{1}, I_{2}$, and $I_{3}$ are different viscous isotropic phases. $L_{1}$ is the aqueous micellar phase. Oil phase region was found to be extremely narrow and limited only in the vicinity of the oil corner of the triangle. No attempt was made concerning the determi= nation of the boundary of the oily isotropic phase region which had been presented by Lachampt $e t a l^{1}$. $\mathrm{E}_{1}$ is the same region that has been shown in Fig.-2.

A diagram for the same ternary system as in the present study has been presented in a sche $=$ matic form by Lachampt et $a l^{1)}$. They devided a micellar phase into two regions, i.e., a micel= lar solution and an emulsoid. The authors denoted these regions as a single phase $L_{1}$, because they seemed to differ from each other only in their appearances due to their micellar sizes.

$\mathrm{I}_{1}$ phase, which is noted as a gel by $\mathrm{La}=$

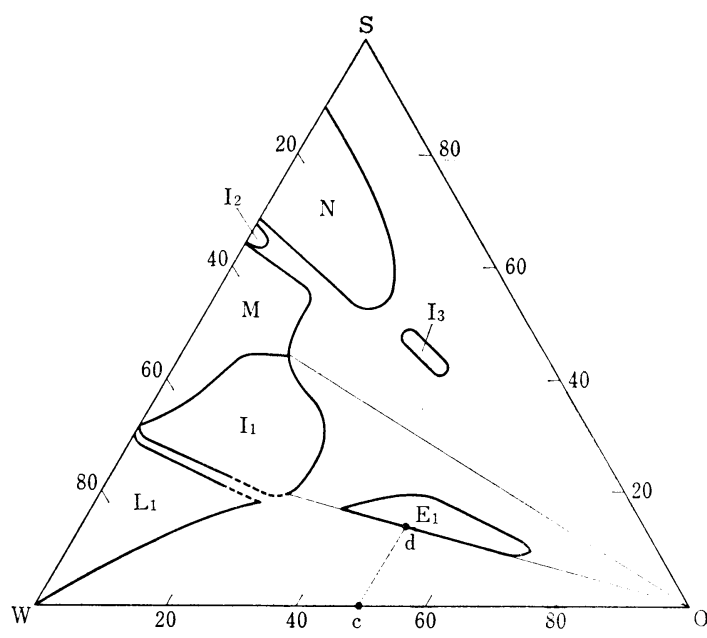

$\mathrm{N}$ : neat phase; $\mathrm{M}$ : middle phase; $\mathrm{I}_{1}, \mathrm{I}_{2}, \mathrm{I}_{3}$ : viscous isotropic phases; $\mathrm{L}_{1}$ : aqueous micellar phase; $\mathrm{E}_{1}$ : stable s.o.e. region.

Fig.-3 Surfactant-oil-water phase diagram. 
champt et al ${ }^{11}$, has been considered to be a ran= dom suspension of the cylindrical micelles ${ }^{8)}$. It exhibits high elasticity and high consistency.

It is apparent from Fig. -3 that the $\mathrm{E}_{1}$ region is confined in the two-phase region, $I_{1}+$ oil, although Lachampt et al. did not refer to this region in detail. The stability of the emulsion in $E_{i}$ can be explained by the fact that the viscous isotropic phase $I_{1}$ constitutes the con= tinuous phase. The high elasticity and high consistency of the emulsions in $\mathrm{E}_{1}$ may be interpreted as the appearance of the intrinsic properties of the $I_{1}$ phase. The three-phase region, $L_{1}+$ oil $+I_{1}$, was not confirmed in the present study. The region was presumed to be very narrow. Strongly opaque $\mathrm{O} / \mathrm{W}$ emulsions were formed in the two-phase region, $\mathrm{L}_{1}+$ oil, but they easily separated aqueous phases. Hence, this region does not belong to the stable s.o.e. region.

Friberg et al..$^{\left.3 \sim)^{6}\right)}$ reported that a sudden in= crease in stability of an emulsion occurred when the composition was varied. They explained the phenomenon as that the lamellar mesomor= phic phase (neat phase) became to coexist with aqueous and oil phases. In the present exper= iment, however, only the region of the emulsions stabilized by the presence of the $I_{1}$ phase was confirmed as a stable s.o.e. region. If the oil content was held constant and the surfactant concentration was raised from the point " $\mathrm{c}$ " in Fig. -3 , also a sudden increase in stability was observed with the abrupt rise in viscosity. A sudden increase in stability occurred almost at the point " $d$ " where the $I_{1}$ phase would begin to coexist. Thus, when the present results are compared with those of Friberg, it is evident that the mesomorphic phases differently con= tribute to the stabilization of emulsions. Such a difference seems to be due to the difference in the constituents adopted. Namely, Friberg used nonylphenyl poly(oxyethylene) (9) ether$p$-xylene-water system ${ }^{5}$. In the ternary diagram studied by Friberg, the neat phase is the most predominant phase, but the middle, phase is very narrow and the $I_{1}$ phase is not seen, the latter two being more hydrophilic phases than neat phase.

Thus, it is found that the s.o.e. region is formed only within the two-phase region where
$I_{1}$ and oil phases coexist, although the emul= sions in $\mathrm{E}_{1}$ may not be called an $\mathrm{O} / \mathrm{W}$ emulsion, since the continuous phase is a mesomorphic one. It is also apparent from Fig. $-\mathbf{3}$ that at least $10 \%$ surfactant is necessary to obtain the stable s.o.e. in the present ternary system.

\subsection{Quarternary System Containing Cetostearyl Alcohol}

Fig. -4 shows the stable and unstable s.o.e. regions when $2 \%$ cetostearyl alcohol is added. By comparing Fig. -4 with Fig. -2 , it is con= firmed that the addition of $2 \%$ alcohol results in the shift of the whole s.o.e. regions toward the lower surfactant concentrations. The stable s.o.e. region of the quarternary system is com= posed of two sub-regions; one in the higher, and the other in the lower surfactant concen= tration regions. The former region corresponds to the $\mathrm{E}_{1}$ region of the ternary system, but the region is slightly shifted as compared with $\mathrm{E}_{1}$ in Fig.-2. The latter region is termed here " $E_{2}$ ". The emulsions in $E_{1}$ in Fig. -4 showed highly viscous properties similar to those in $\mathrm{E}_{\text {i }}$ in Fig. -2 . The emulsions in $\mathrm{E}_{2}$ were in general semi-solid, although they showed less resistance to flow than those in $E_{1}$.

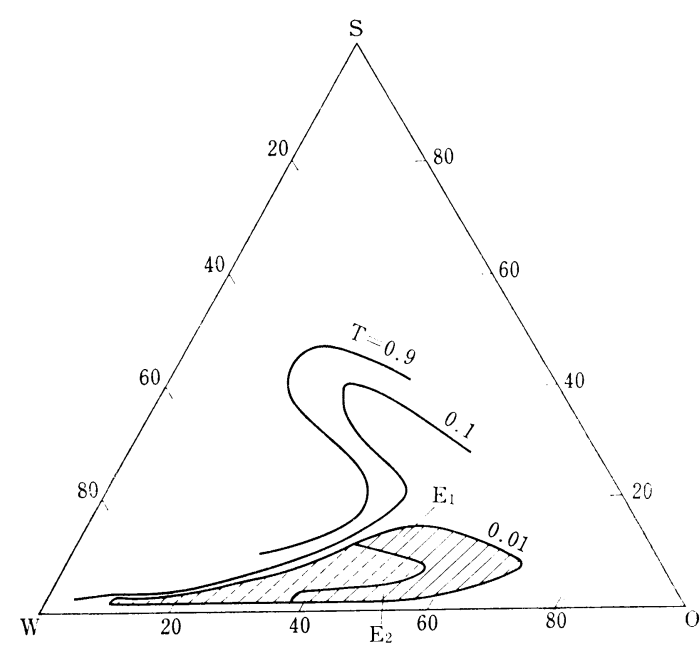

$$
\mathrm{E}_{1}, \mathrm{E}_{2} \text { : stable s.o.e. regions. }
$$

Fig.-4 Transmittance of quarternary system containing $2 \%$ cetostearyl alcohol.

Fig. -5 and 6 show the quarternary diagrams when the cetostearyl alcohol content was varied from 0 to $4 \%$. From these figures, the follow $=$ ing tendencies will be confirmed. 
1) The $E_{1}$ region shifts toward the lower surfactant concentration as the alcohol content increases.

2) The $E_{2}$ region begins to appear when the alcohol content reaches about 1.5\% and the $\mathrm{E}_{1}$ region almost disappears when the alcohol con= tent increases up to $4 \%$.

3) $E_{1}$ and $E_{2}$ regions coexist when the alcohol content is between $1.5 \%$ and $3 \%$ (the diagram of $3 \%$ alcohol is not shown).

4) (n the lower oil content part of the s.o.e. region, $E_{1}$ and $E_{2}$ are separated from each other, the unstable and fluid s.o.e. region lying between them. In the higher oil content region, $\mathrm{E}_{1}$ and $\mathrm{E}_{2}$ become contiguous.

5) The further increase of the alcohol con= tent shifts the $\mathrm{E}_{2}$ region toward the lower oil content. The resultant $\mathrm{E}_{2}$ region becomes con= siderably narrow.

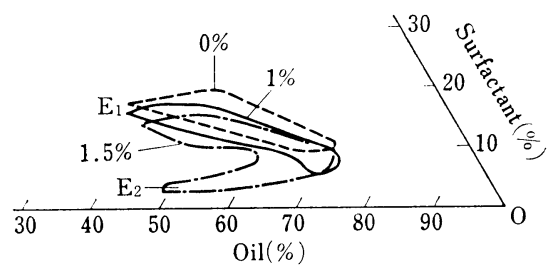

Fig.-5 Stable s.o.e. regions in quarternary systems containing $0 \sim 1.5 \%$ cetostearyl alcohol.

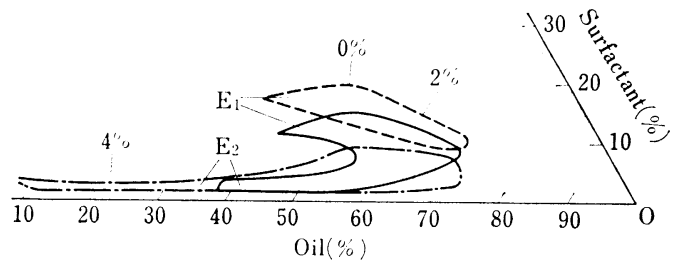

Fig.-6 Stable s.o.e. regions in quarternary systems containing $0 \sim 4 \%$ cetostearyl alcohol.

The emulsions in $E_{2}$ are stabilized by the presence of the hydrophilic surfactant and cetostearyl alcohol, and they are presumed to be closely related to the emulsions studied by Barry et at. ${ }^{9) \sim 13)}$ and Talman et al. ${ }^{14) \sim 16)}$ in the emulsion structure. Barry referred to the selfbodying action as the interaction of a long chain alcohol with a hydrophilic surfactant solution to form a visco-elastic gel-network in the contin= uous phase of $\mathrm{O} / \mathrm{W}$ emulsion. The $\mathrm{E}_{2}$ region in this study might correspond to the composition range where such an action can play a role to stabilize the emulsions.

The anisotropic structure was often observed around the oil droplets of the emulsions in $\mathrm{E}_{2}$. This is presumed to be a liquid crystalline structure, which might be similar to that re= ported by other authors ${ }^{12), 13), 18) \sim 20}$.

Thus, by adding cetostearyl alcohol to the surfactant-oil-water ternary system, it becomes possible to reduce the minimum surfactant concentration to a great extent which is neces= sary to prepare a stable emulsion. In this way, if $4 \%$ alcohol is added, a stable emulsion can be obtained with least possible surfactant con= centration of about $2 \%$, over the wide range of oil content from about $10 \%$ to $70 \%$. In fact, cetostearyl alcohol is used widely in prace tical $\mathrm{O} / \mathrm{W}$ emulsions in conjunction with some surfactants. So, it seems likely that such a region as $\mathrm{E}_{2}$ has been utilized in the emulsion formu= lations of cosmetics and pharmaceuticals. There $=$ fore, it may be worthwhile to study the conditions to obtain a wide composition range of the region $\mathrm{E}_{2}$.

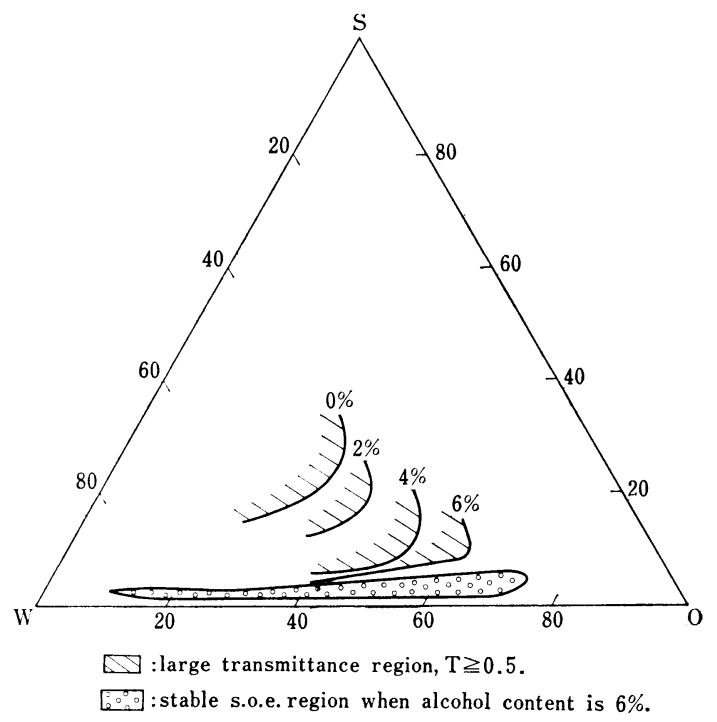

Fig.-7 Extention of large transmittance region with cetostearyl alcohol content $(0 \sim 6 \%)$.

Fig.-7 shows the extension of the large transmittance region $(T \geqq 0.5)$ with the ceto= stearyl alcohol content $(0 \sim 6 \%)$. The stable s.o.e. region of $6 \%$ alcohol content is also shown in Fig. -7 . The large transmittance region 
extended toward the oil corner of the diagram as the alcohol content increased. This occurred probably because micelles became more swollen with increasing amount of the alcohol to solu= bilize much more oil. Furthermore, if the large transmittance region extends with increasing cetostearyl alcohol content, the $\mathrm{E}_{1}$ region is expected to shift and eventually almost disappear. As shown in Fig.-7, when the alcohol content is $6 \%$, the stable s.o.e. region consists only of the $E_{2}$ region as a result of the entire disap= pearance of $E_{1}$.

\subsection{Quarternary System Containing Various Long Chain Alcohols}

Fig.-8 shows the diagrams of quarternary systems in which the fourth components are cetostearyl alcohol, $\mathrm{C}_{12} \mathrm{OH}, \mathrm{C}_{16} \mathrm{OH}$, and $\mathrm{C}_{20} \mathrm{OH}$. In each diagram of Fig.-8, the oil content is kept constant at 50\% and two variables are surfactant and alcohol contents. Here, the alcohol content is also shown as an additional amount (\%) to the total amount (equal to 100\%) of surfactant, oil, and water. Dashed curves represent the equi-transmittance curves of $T=$ 0.01 . Areas with shadows are the stable s.o.e. regions. The upper part than the dashed curves is the region of $T$ larger than 0.01 , namely the
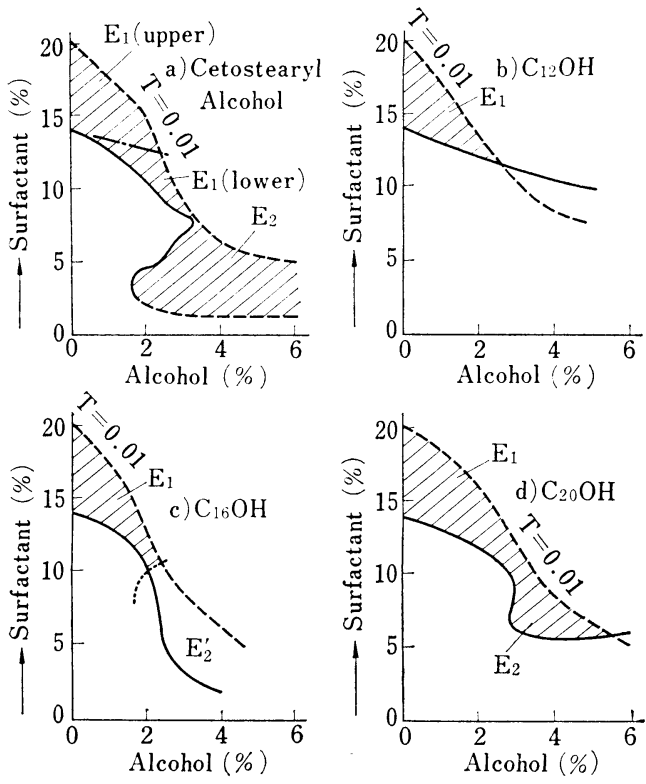

Fig.-8 Stable s.o.e. regions in quarternary systems (oil : 50\%). Dependence upon $\mathrm{C}_{12} \sim \mathrm{C}_{20}$ alcohol addition. region of decreasing opacity. In the region lower than the solid curves, emulsion stability tended to decrease, separating aqueous phase.

\subsubsection{Cetostearyl Alcohol}

Fig, -8 (a) shows the diagram for the system containing cetostearyl alcohol as a fourth com= ponent. As the alcohol content increased, the $\mathrm{E}_{1}$ region shifted toward the lower surfactant concentration and became narrow. when the alco= hol content was about $3.5 \%, \mathrm{E}_{1}$ region entirely disappeared. This disappearance of $E_{1}$ may be caused by the increase in $T$ with the increasing amount of the alcohol. For example, when the surfactant concentration was kept constant at $15 \%$ and the alcohol content was gradually increased, $T$ reached 0.01 at the content of about $2 \%$, and rose up to 0.5 at $3.2 \%$. When the content was $3.2 \%$, no oil droplets were seen under the optical microscope, and so-called microemulsion might form. In the upper part of $E_{1}$ in Fig.-8 (a), the rheological properties were similar to that of $I_{1}$ phase. At the boundary of the upper and lower parts of $E_{1}$, viscosity changed abruptly, and in the lower part, the system remained semi-solid but turned to show less resistance to flow. So, the influence of $I_{1}$ phase may be restricted to the upper part of $E_{1}$. In the lower part of $E_{1}$, the continuous phase structure may be much weaker tnan that of $I_{1}$ phase. Below $\mathrm{E}_{1}$ region, emulsions were fluid, and ready to separte aqueous phases.

$\mathrm{E}_{2}$ region began to appear at the lower sur= factant concentration when the alcohol content reached about $1.5 \%$. Owing to this appearance of $E_{2}$, the minimum surfactant concentraion required for obtaining stable s.o.e. can be effec $=$ tively reduced to about $2 \%$, if more than $1.5 \%$ alcohol is added. Droplets became finer and $T$ exceeded 0.01 above the $\mathrm{E}_{2}$ region. $T$ also exceeded 0.01 below the $E_{2}$ region but this is due to the oil droplets becoming larger because of insufficient surfactant concentration.

The processes of the shift and disappearance of $E_{1}$, and the appearance of $E_{2}$ with the in= creasing amount of the alcohol corresponds to those shown in Fig. -5 and 6 .

\section{$3 \cdot 3 \cdot 2 \quad \mathrm{C}_{12} \mathrm{OH}$}

Fig. -8 (b) shows the diagram for the system containing $\mathrm{C}_{12} \mathrm{OH}$ as a fourth component. In this case, stable s.o.e. region of $E_{1}$ appeared 
but $\mathrm{E}_{2}$ was lacking. Thus, $\mathrm{C}_{12} \mathrm{OH}$ was proved not effective as a stabilizer for the emulsion through the formation of $\mathrm{E}_{2}$ region.

\section{$3 \cdot 3 \cdot 3 \quad \mathrm{C}_{16} \mathrm{OH}$}

Fig.-8 (c) shows the diagam for the system containing $\mathrm{C}_{16} \mathrm{OH}$. Emulsions in the " $\mathrm{E}_{2}$ " " region was semi-solid but on storage they tended to separate oil phases. As a result, only the $E_{t}$ region remained as the stable s.o.e. region. In the case of the system containing $\mathrm{C}_{14} \mathrm{OH}$, similar results were obtained, although not illustrated here.

\section{$3 \cdot 3 \cdot 4 \quad \mathrm{C}_{20} \mathrm{OH}$}

Fig.-8 (d) shows the diagram for the system containing $\mathrm{C}_{20} \mathrm{OH}$. For the system containing $\mathrm{C}_{18} \mathrm{OH}$, a similar diagram was obtained. $\mathrm{C}_{18}$ $\mathrm{OH}$ and $\mathrm{C}_{20} \mathrm{OH}$ gave the $\mathrm{E}_{2}$ region in addition to the region $\mathrm{E}_{1}$, but only above the surfactant concentration of about 5\%. Below about $5 \%$, emulsions had been semi-solid for a few deys or a few weeks after preparation, but afterwards they turned fluid and separated aqueous phases. The separation of the emulsions was accompanied by the deposition of crystalline-like materials, probably the alcohol. The lower the surfactant concentration became, the sooner occurred these phenomena. Similar phenomena were presented by other authors ${ }^{17), 20)}$. Fukushima et al. dis= cussed such phenomena from a view point of polymorphism of the alcohols ${ }^{17), 18}$.

\section{$3 \cdot 3 \cdot 5$ Comparison of the Alcohols}

$\mathrm{C}_{12} \mathrm{OH}$ gave no $\mathrm{E}_{2}$ region. $\mathrm{C}_{14} \mathrm{OH}$ and $\mathrm{C}_{16} \mathrm{OH}$ gave the $\mathrm{E}_{2}{ }^{\prime}$ region in which the emulsions were semi-solid but unstable. So, according to the concept of Barry's, the self-bodying action does not appear in the case of $\mathrm{C}_{12} \mathrm{OH}$, while in the case of $\mathrm{C}_{14} \mathrm{OH}$ and $\mathrm{C}_{16} \mathrm{OH}$, the action may

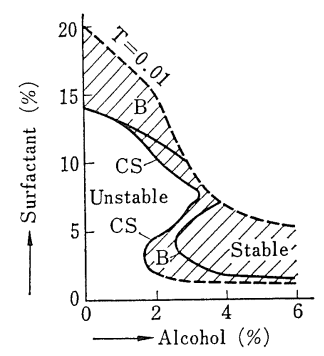

Fig.-9 Stable s.o.e. region when fourth component is cetostearyl alcohol (CS) or behenyl alcohol (B). appear to some extent but on storage it may be weakened. $\mathrm{C}_{18} \mathrm{OH}$ and $\mathrm{C}_{20} \mathrm{OH}$ gave the $\mathrm{E}_{2}$ region but its minimum surfactant concentration could not be reduced to less than about 5\%. On the other hand, cetostearyl alcohol, whose main components were $\mathrm{C}_{16} \mathrm{OH}$ and $\mathrm{C}_{18} \mathrm{OH}$, gave $\mathrm{E}_{2}$ region extending over a wide range of alcohol content. Its minimum surfactant concentration was about $2 \%$, which was about $3 \%$ lower than that in the case of $\mathrm{C}_{18} \mathrm{OH}$ or $\mathrm{C}_{20} \mathrm{OH}$.

As shown in Fig.-9, behenyl alcohol of cosmetic grade, which is the mixture composed mainly of $\mathrm{C}_{22} \mathrm{OH}, \mathrm{C}_{20} \mathrm{OH}$, and $\mathrm{C}_{18} \mathrm{OH}$, also gave the $\mathrm{E}_{2}$ region of sufficient stability. The minic mum surfactant concentration of the $\mathrm{E}_{2}$ region was about $2 \%$ similar to the case of cetostearyl alcohol. But the minimum alcohol content was about $2.5 \%$ which was about $1 \%$ higher than that in the case of cetostearyl alcohol. It is desirable for the practical emulsion formulations that the stable s.o.e. can be obtained in the wider composition range at the lower surfactant concentration on the diagram. From these points of view, the mixture of the alcohols such as cetostearyl and behenyl alcohols is preferable to the pure alcohols ranging from $\mathrm{C}_{12}$ to $\mathrm{C}_{20}$, as far as the present study is concerned.

(Received Dec. 22, 1978)

\section{References}

1) F. Lachampt and R.M. Vila, Am. Perfumer Cosmet., 82 (1), 29 (1967).

2) F. Lachampt and R.M. Vila, Am. Perfumer Cosmet., 85 (1), 27 (1970).

3) S. Friberg, L. Mandell, and M. Larsson, J. Colloid Interface Sci., 29, 155 (1969).

4) S. Friberg and L. Rydhag, Kolloid-Z. Z. Polym., 244, 233 (1971).

5) S. Friberg and I. Wilson, Am. Perfumer Coss met., 85 (12), 27 (1970).

6) S. Friberg, J. Colloid Interface Sci., 37, 291 (1971).

7) I. Lo, A.T Florence, J. Treguier, M. Seiller, and F. Puisieux, J. Colloid Interface Sci., 59, 319 (1977).

8) F.B. Rosevear, J. Soc. Cosmet. Chemists, 19, 581 (1968).

9) B.W. Barry and E. Shotton, J. Pharm. Phars macol., 19, 110s (1967). 
10) B.W. Barry, J. Colloid Interface Sci., 28, 82 (1968).

11) B.W. Barry, J. Colloid Interface Sci., 32, 551 (1970).

12) B.W. Barry and G.M. Saunders, J. Colloid Interface Sci., 38, 616 (1972)

13) B.W. Barry and G.M. Saunders, J. Colloid Interface $S_{c i}$., 38, 626 (1972).

14) F.A.J. Talman, P.J. Davies, and E.M. Rowan, J. Pharm. Pharmacol., 19, 417 (1967)

15) F.A.J. Talman and E.M. Rowan, J. Pharm. Pharmacol., 22, 338 (1970).

16) F.A.J. Talman and E.M. Rowan, J. Pharm. Pharmacol., 22, 417 (1970).

17) S. Fukushima, M. Takahashi, and M. Yama= guchi, J. Colloid Interface Sci., 57, 201 (1976).

18) S. Fukushima, M. Yamaguchi, and F. Haru= sawa, J. Colloid Interface Sci., 59, 159 (1977).

19) G.M. Eccleston, J. Colloid Interface Sci., 57, 66 (1976).

20) G.E. Mapstone, Cosmet. Perfum., 89 (11), 31 (1974).
界面活性剤-油-水系及び界面活性剂-油 一水一長鎖アルコール系に打ける安定 エマルション領域

次田 章・西島 靖・传々木恒孝 鐘紡怢式会社化精品研究听・東海大学理学湖

非イオン界面活性剤一油-水三成分系の状態図を調心゙, 安定かつ乳白度大なるエマルション領域 ( $\mathrm{E}_{1}$ 領域) その状態図上で求めた。その結果， $\mathrm{E}_{1}$ 領域は粘ちゅう 等方性相々油相からなる二相共存領域内にのみ存在する こと，及びこの領域を得るためには少なくとも10\%の 界面活性剂が必要であることがわかった。

次いで，この三成分にセトステアリルアルコールを加 えた四成分系について調べた。セトステアリルアルコー ルの添加により, 乳白度大なるエマルションの新たな安 定領域 ( $\mathrm{E}_{2}$ 領域) が $\mathrm{E}_{1}$ 領域のほかに生成した。この $\mathrm{E}_{2}$ 領域の出現は, 安定かつ乳白度大なるエマルションを得 るための最少界面活性剂濃度を約 $2 \%$ まで減少させた。 同様に混合アルコールである化粧品グレードのベへニル アルコールについても同じような効果が見られた。しか し炭素数 12 から 16 の各アルコールは $\mathrm{E}_{2}$ 領域を生成さ せる能力に久けていた。また炭素数 18 と 20 のアルコー ルは $\mathrm{E}_{2}$ 領域を生成させたが，いずれも界面活性剤濃度 $5 \%$ 以上の領域に限定されていた。 